\title{
In vitro insulin action on erythrocyte glucose metabolism in normal and diabetic rats
}

\author{
V. R. Agarwal, A. K. Rastogi and P. Sagar \\ Division of Biochemistry, Central Drug Research Institute, Lucknow, India
}

Summary. Alloxan-induced diabetes in rats significantly impaired the capacity of the erythrocytes to metabolise glucose in vitro to either lactic acid or $\mathrm{CO}_{2}$. Both these metabolic activities were initially insensitive to insulin in normal as well as in diabetic animals; but became responsive when these cells were subjected to insulin and glucose 'starvation' for $1 \mathrm{~h}$ through incubation in their absence. This action of insulin in starved cells showed concentration dependence and required preincubation with the hormone prior to addition of glucose.

Key words: Insulin, erythrocyte, diabetes, glucose metabolism, rat.
Whereas erythrocytes have generally been considered insensitive to insulin in the past, Gambhir et al. [1] demonstrated the presence of insulin receptors on these cells, whose characteristics resembled the properties of hormone receptors of classical target tissues e.g. liver, fat and muscle cells. Further, we have observed changes in the $\mathrm{Na}^{+}+\mathrm{K}^{+}$and $\mathrm{Ca}^{2+}$-ATPases [2] and acetylcholinesterase [3] in erythrocyte ghosts on in vitro incubation with the hormone. Baldini et al. [4] recently reported that contrary to an inhibitory response of insulin towards ghost $\mathrm{Na}^{+}+\mathrm{K}^{+}$-ATPase, exposure of intact erythrocytes to the hormone may stimulate its Na-pumping mechanism. A similar response of insulin was noted earlier in frog skeletal muscle, which Moore [5] considered to be indirectly responsible for some of the well-known physiological responses of the hormone, including the modulation of glycolysis through an indirect influence on phosphofructokinase.

The erythrocyte system lacks the citric acid cycle and metabolises sugars partly to lactic acid through glycolysis and partly to $\mathrm{CO}_{2}$ through the hexose monophosphate shunt. However, the response of erythrocyte carbohydrate metabolism to insulin has apparently not yet been investigated. The present communication deals with the action of insulin on the formation of lactic acid and $\mathrm{CO}_{2}$ from glucose in the erythrocytes of normal and diabetic (alloxan-induced) rats in vitro.

\section{Materials and methods}

\section{Experimental animals}

Male Sprague-Dawley rats (200-250 g) were fed a Hindustan Liver Pellet diet and maintained in the animal house of the Central Drug Research Institute. Diabetes was induced by treatment with alloxan as reported earlier [2]. The mean blood glucose value of diabetic rats was $19.44 \pm 1.1 \mathrm{mmol} / 1$ of blood.

D-[U- $\left.{ }^{14} \mathrm{C}\right]$-glucose (specific activity $255 \mathrm{mCi} / \mathrm{mmol}$ ) was obtained from Bhabha Atomic Research Centre (Bombay, India) and porcine insulin was procured from the Sigma Chemical Company (St. Louis, Mo, USA). All other chemicals were of analytical grade and were provided by BDH or E. Merck (Bombay, India).

\section{Preparation of erythrocyte suspension and glucose oxidation studies}

The preparation of the erythrocyte suspension and the measurement of ${ }^{14} \mathrm{CO}_{2}$ production from ${ }^{14} \mathrm{C}$-(U)-glucose was carried out according to the method of Kelman et al. [6] using Warburg flasks. To $2 \mathrm{ml}$ of erythrocyte suspension in Krebs-Ringer phosphate buffer (without glucose) was added the required insulin concentration. After preincubation with the hormone, the reaction was started by adding $5 \mathrm{mmol} / 1$ glucose supplemented with $0.5 \mu \mathrm{Ci}{ }^{14} \mathrm{C}$-(U)-glucose (specific activity $255 \mathrm{mCi} / \mathrm{mmol}$ ). The reaction was stopped by the addition of $0.6 \mathrm{ml}$ of $35 \%$ perchloric acid. Appropriate controls in which perchloric acid was added before the addition of glucose were always simultaneously set up.

\section{Lactic acid estimation}

The perchloric acid-treated cells from the flasks were transferred to centrifuge tubes and made up to $5 \mathrm{ml}$ with distilled water. After centrifugation at $400 \mathrm{~g}$ for $10 \mathrm{~min}, 1 \mathrm{ml}$ of the supernatant was taken and lactic acid estimated using the colorimetric method of Barker and Summerson [7].

\section{Statistical analysis}

All results are presented as mean \pm SD of 4 experiments. The significance of difference was evaluated by Student's t-test.

\section{Results}

Action of insulin on $\mathrm{CO}_{2}$ and lactic acid generation from glucose was studied under two sets of conditions. 
Table 1. Effect of insulin on ${ }^{14} \mathrm{CO}_{2}$ production from ${ }^{14} \mathrm{C}$-(U)-glucose in erythrocytes of normal and diabetic rats

\begin{tabular}{llllll}
\hline $\begin{array}{l}\text { Concen- } \\
\text { tration } \\
\text { of } \\
\text { insulin } \\
\text { (mol/1) }\end{array}$ & \begin{tabular}{l} 
Normal rats \\
\cline { 5 - 6 } Wreincu- \\
bation
\end{tabular} & $\begin{array}{l}\text { With } \\
\text { preincu- } \\
\text { bation }\end{array}$ & $\begin{array}{l}\text { Wiabetic rats } \\
\text { Wreincul } \\
\text { bation }\end{array}$ & $\begin{array}{l}\text { With } \\
\text { preincu- } \\
\text { bation }\end{array}$ \\
\hline 0 & $(1.0 \pm 0.15)^{\mathrm{a}}$ & $(0.98 \pm 0.08)$ & $(0.75 \pm 0.12)$ & $(0.79 \pm 0.09)$ \\
& $1.03 \pm 0.095$ & $1.00 \pm 0.08$ & $0.73 \pm 0.13$ & $0.72 \pm 0.10$ \\
$10^{-10}$ & $1.00 \pm 0.10$ & $1.18 \pm 0.13$ & $0.76 \pm 0.09$ & $0.92 \pm 0.13$ \\
& $p>0.05$ & $p>0.05$ & $p>0.05$ & $p>0.05$ \\
$10^{-9}$ & $1.02 \pm 0.11$ & $1.29 \pm 0.18$ & $0.72 \pm 0.10$ & $0.98 \pm 0.09$ \\
& $p>0.05$ & $p<0.05$ & $p>0.05$ & $p<0.01$ \\
$10^{-8}$ & $1.07 \pm 0.16$ & $1.34 \pm 0.15$ & $0.78 \pm 0.11$ & $1.03 \pm 0.18$ \\
& $p>0.05$ & $p<0.01$ & $p>0.05$ & $p<0.05$ \\
$10^{-7}$ & $1.09 \pm 0.14$ & $1.41 \pm 0.18$ & $0.81 \pm 0.12$ & $1.08 \pm 0.19$ \\
& $p>0.05$ & $p<0.01$ & $p>0.05$ & $p<0.02$ \\
& $(1.11 \pm 0.14)$ & $(0.94 \pm 0.08)$ & $(0.74 \pm 0.07)$ & $(0.83 \pm 0.05)$ \\
\hline
\end{tabular}

a All data are relative to this value. The values in parentheses represent the data for normal erythrocytes while the other data are for starved cells

Table 2. Effect of insulin on increase in lactic acid levels in erythrocytes of normal and diabetic rats

\begin{tabular}{|c|c|c|c|c|}
\hline \multirow{2}{*}{$\begin{array}{l}\text { Concen- } \\
\text { tration } \\
\text { of } \\
\text { insulin } \\
(\mathrm{mol} / \mathrm{l})\end{array}$} & \multicolumn{2}{|l|}{ Normal rats } & \multicolumn{2}{|l|}{ Diabetic rats } \\
\hline & $\begin{array}{l}\text { Without } \\
\text { preincu- } \\
\text { bation }\end{array}$ & $\begin{array}{l}\text { With } \\
\text { preincu- } \\
\text { bation }\end{array}$ & $\begin{array}{l}\text { Without } \\
\text { preincu- } \\
\text { bation }\end{array}$ & $\begin{array}{l}\text { With } \\
\text { preincu- } \\
\text { bation }\end{array}$ \\
\hline 0 & $\begin{array}{c}(1.00 \pm 0.09)^{\mathrm{a}} \\
1.05 \pm 0.05\end{array}$ & $\begin{array}{c}(1.11 \pm 0.10) \\
1.01 \pm 0.06\end{array}$ & $\begin{array}{c}(0.80 \pm 0.07) \\
0.81 \pm 0.08\end{array}$ & $\begin{array}{c}(0.81 \pm 0.08) \\
0.80 \pm 0.09\end{array}$ \\
\hline $10^{-10}$ & $\begin{array}{l}0.99 \pm 0.06 \\
p>0.05\end{array}$ & $\begin{array}{l}1.20 \pm 0.10 \\
p<0.02\end{array}$ & $\begin{array}{l}0.76 \pm 0.04 \\
p>0.05\end{array}$ & $\begin{array}{l}1.00 \pm 0.08 \\
p<0.02\end{array}$ \\
\hline $10^{-9}$ & $\begin{array}{l}1.07 \pm 0.09 \\
p>0.05\end{array}$ & $\begin{array}{l}1.42 \pm 0.16 \\
p<0.005\end{array}$ & $\begin{array}{l}0.80 \pm 0.08 \\
p>0.05\end{array}$ & $\begin{array}{l}1.16 \pm 0.10 \\
p<0.005\end{array}$ \\
\hline $10^{-8}$ & $\begin{array}{l}1.08 \pm 0.09 \\
p>0.05\end{array}$ & $\begin{array}{l}1.55 \pm 0.15 \\
p<0.001\end{array}$ & $\begin{array}{l}0.85 \pm 0.10 \\
p>0.05\end{array}$ & $\begin{array}{l}1.34 \pm 0.14 \\
p<0.001\end{array}$ \\
\hline $10^{-7}$ & $\begin{array}{l}1.11 \pm 0.11 \\
p>0.05 \\
(1.01 \pm 0.06)\end{array}$ & $\begin{array}{c}1.62 \pm 0.14 \\
p<0.001 \\
(1.06 \pm 0.05)\end{array}$ & $\begin{array}{l}0.84 \pm 0.09 \\
p>0.05 \\
(0.85 \pm 0.04)\end{array}$ & $\begin{array}{c}1.43 \pm 0.13 \\
p<0.001 \\
(0.78 \pm 0.09)\end{array}$ \\
\hline
\end{tabular}

a All data are relative to this value. The values in parentheses represent the data for normal erythrocytes while the other data are for starved cells

Either the hormone and ${ }^{14} \mathrm{C}$-(U)-glucose were added simultaneously (designated 'without preincubation' in Tables), or cells were incubated at $37^{\circ} \mathrm{C}$ with the hormone for $1 \mathrm{~h}$ prior to addition of glucose, followed by further incubation for $1 \mathrm{~h}$ (designated "with preincubation' in Tables). In each case perchloric acid was added $1 \mathrm{~h}$ after addition of glucose, and the production of ${ }^{14} \mathrm{CO}_{2}$ and lactic acid were estimated.

The results suggested that the $\mathrm{CO}_{2}$ output, which in this system is a measure of the hexose-monophosphate shunt, is impaired by $20-25 \%$ in the diabetic animals $(p<0.05)$ (Table 1). Insulin, whether supplied $1 \mathrm{~h}$ before or along with ${ }^{14} \mathrm{C}$-glucose did not exercise any significant $(p>0.05)$ influence on ${ }^{14} \mathrm{CO}_{2}$ production in either group (Table 1).
The initial lactic acid content of the normal (nonstarved) erythrocyte suspension in each flask (see Materials and methods) was found to be $82 \pm 8 \mu \mathrm{g}$, which increased to $181 \pm 14 \mu \mathrm{g}$ during $1 \mathrm{~h}$ incubation with exogenous glucose, presumably due to lactic acid formation through glycolysis. Essentially similar results were obtained with erythrocytes of diabetic rats except that the lactic acid values were lower both before and after metabolism of exogenous glucose (Table 2). Like $\mathrm{CO}_{2}$ production, the lactic acid increase was not significantly $(p>0.05)$ influenced by insulin under the above conditions (Table 2); nor did preincubation with different insulin concentrations bring about any significant $(p>0.05)$ change in the basal lactic acid levels (data not presented).

In another series of experiments the erythrocytes were preincubated for $1 \mathrm{~h}$ without any exogenous glucose or insulin and the effect of insulin on ${ }^{14} \mathrm{CO}_{2}$ production and lactic acid levels were studied. Both ${ }^{14} \mathrm{CO}_{2}$ production and lactic acid increase were now found to be sensitive to insulin. However, the stimulatory response of insulin manifested itself only after preincubation of the cells with the hormone before the addition of glucose (Tables 1 and 2). These responses depended on the hormone concentration and were higher in the erythrocytes of diabetic animals when expressed as percentage increase over respective non-insulin controls. These increases were statistically significant in both groups $(p<0.01-0.05)$ except at $10^{-10} \mathrm{~mol} / 1$ in the case of $\mathrm{CO}_{2}$ production $(p>0.05)$ (Table 1).

\section{Discussion}

The above results demonstrate that although the metabolism of glucose both through the glycolytic and hexose monophosphate shunt mechanisms is unresponsive to insulin in normal erythrocytes, it is rendered hormone sensitive by a brief incubation of these cells in a glucose and insulin-deficient environment. Goodman and Cairo [8] reported that preincubation of rat adipose tissue resulted in marked stimulation of the insulin-like response to growth hormone, and that to insulin itself, of $\mathrm{CO}_{2}$ production from glucose, although the latter was not found to be as consistent.

The observation that stimulation of $\mathrm{CO}_{2}$ and lactic acid generation from glucose by starved erythrocytes required their preincubation with insulin suggests that both these effects may be receptor mediated. One possible explanation for insensitivity of normal (unstarved) cells could thus be inadequate availability of vacant hormone receptor sites, due to their prior interaction with insulin in circulation. On incubation in the absence of the hormone, their availability may increase through receptor recyclisation [9] and/or degradation of receptor-bound hormone through the action of insulin degrading enzymes [10]. However, if this postulate 
holds true, one would expect erythrocytes to be prepared in insulin-activated state, and hence some reduction in their basal capacity to metabolise glucose on being incubated in insulin deficient medium. This was not generally observed in our experiments and further work is thus needed to satisfactorily explain the present observations.

Acknowledgements. The present study was supported by grants from the Council of Scientific and Industrial Research, India. Technical assistance by Mr. R.K. Vaish is gratefully acknowledged.

\section{References}

1. Gambhir KK, Archer JA, Bradley CJ (1978) Characteristics of human erythrocyte insulin receptors. Diabetes 27: 701-708

2. Agarwal VR, Rastogi AK, Sahib MK, Sagar P (1985) In vitro insulin action on different ATPases of erythrocyte membranes in normal and diabetic rats. Acta Diabetol Lat 22: 111-118

3. Agarwal VR, Rastogi AK, Sahib MK, Sagar P (1985) In vitro insulin effect on acetylcholinesterase of erythrocyte membranes of normal and diabetic rats. Acta Diabetol Lat 22: 359-363

4. Baldini P, Incerpi S, Pascale E, Rinaldi C, Verna R, Luly P (1986) Insulin effects on human red blood cells. Mol Cell Endocrinol 46: 93-102
5. Moore RD (1983) Effect of insulin upon ion transport. Biochim Biophys Acta 737: 1-49

6. Kelman SN, Sullivan SG, Stern A (1981) Chloroquine and Primaquine induced alteration of glucose metabolism in the infected red cell. Biochem Pharmacol 30: 81-87

7. Barker SB, Summerson WH (1941) The colorimetric determination of lactic acid in biological materials. J Biol Chem 138: 535-554

8. Goodman HM, Cairo V (1981) Induction of sensitivity to the insulin like action of growth hormone in normal rat adipose tissue. Endocrinology 108: 113-119

9. Peterson SW, Miller AL, Kelleher RS, Murray EF (1983) Insulin receptor down regulation in human erythrocytes. $\mathbf{J}$ Biol Chem 258: 9605-9607

10. Gambhir KK, Nerurkar SG, Das PD, Archer JA, Henry WL (1981) Insulin binding and degradation by human erythrocytes at Physiological temperature. Endocrinology 109: 1787-1789

Received: 21 July 1987

and in revised form: 22 October 1987

\section{Dr. P. Sagar}

Biochemistry Division

Central Drug Research Institute

Lucknow

India 